\title{
INTERVENSI BERBASIS WEB SWADAYA TERAPI \\ SEBAGAI ALTERNATIF PROGRAM PENINGKATAN KETERAMPILAN BELAJAR MAHASISWA
}

\author{
Eka Wahyuni, Djunaedi, Nabilah \\ e-mail: wahyuni.eka@gmail.com \\ Bimbingan \& Konseling, FIP UNJ
}

\begin{abstract}
Abstrak: Penelitian ini mengkaji kerangka kerja konseptual dan basis empiris intervensi berbasis web swadaya terapi (Self-Help Web-Based Theraputic Intervention) sebagai program alternatif untuk meningkatkan kemampuan belajar siswa dalam pendidikan tinggi. Urgensi untuk menyediakan layanan online melalui swadaya intervensi terapi berbasis web ini ditunjukkan dengan partisipasi dan kemampuan belajar digital siswa hasil. Penelitian ini dilaksanakan Mei sampai dengan November 2013. Dalam penelitian ini, 326 mahasiswa berpartisipasi dalam survei yang melibatkan 7 fakultas di Universitas Negeri Jakarta. Hasil penelitian menunjukkan, lebih dari lima puluh persen mahasiswa di Universitas Negeri Jakarta memiliki kemampuan belajar yang rendah. Kondisi ini harus secara proaktif merespon dengan ketentuan Program online karena untuk meningkatkan prestasi siswa. Sebagai peserta aktif dalam dunia digital, siswa akan lebih memilih lebih banyak untuk layanan online intervensi terapeutik yaitu self-help berbasis web. Berdasarkan temuan, saran dan implikasi dibuat untuk website Tanya Binga.

Kata kunci: intervensi terapi berbasis web self-help, kemampuan belajar.

\section{SELF-HELP WEB-BASED THERAPUTIC INTERVENTION AS AN ALTERNATIVE PROGRAM TO IMPROVE THE STUDENTS' LEARNING SKILL}

\begin{abstract}
This research investigates conceptual framework and empirical bases of web-based self-help therapeutic intervention as an alternative programme to enhance students' study skills in higher education. Urgency to provide online services through web-based self-help therapeutic intervention is indicated by students' digital participation and study skills result. In this study, 326 college students participated in the survey involving 7 faculties in The State University of Jakarta. The result shows that more than fifty per cent of undergraduate students in State University of Jakarta have low study skills. This condition has to proactively respond by online programme provision due to boost students' achievement. As an active participant in digital world, students would prefer more to online services namely self-help web-based therapeutic intervention. Based on the findings, suggestions and implication were made for Tanya Binga website.
\end{abstract}

Key word: self-help web-based therapeutic intervention, study skills.

\section{PENDAHULUAN}

Keterampilan belajar pada tingkat pendidikan tinggi merupakan hal yang esensial dimiliki oleh mahasiswa karena akan mendukung kesuksesan dalam menjalankan proses perkuliahan dengan segala tuntutan tugas-tugas baik yang bersifat teoritik maupun kinerja. hal ini sejalan dengan tujuan Pendidikan tinggi yang merupakan institusi yang diselenggarakan dalam rangka menyiapkan peserta didik menjadi anggota masyarakat yang memiliki kemampuan akademik dan/atau profesional yang dapat menerapkan, mengembangkan dan/atau menciptakan ilmu pengetahuan. teknologi dan/atau kesenian (Keputusan Menteri Pendidikan Nasional
Republik Indonesia Nomor 232/U/2000. Perguruan Tinggi bukan hanya berperan dalam mempersiapkan tenaga ahli dan profesional yang siap memasuki dunia lulusan PT adalah tenaga ahli dan profesional yang siap memasuki dunia kerja (usaha dan industri) ataupun membuka lapangan kerja baru, namun yang lebih penting adalah membangun critical mass dan menjadi kekuatan untuk akselerasi pertumbuhan dan perubahan ekonomi dan penguatan daya saing bangsa.

Untuk itu pemerintah mengembangkan standar penyetaraan sumber daya manusia Indonesia melalui Peraturan Presiden No. 8/2012 Kerangka Kualifikasi Nasional Indonesia (KKNI) - Indonesian Qualification Framework (IQF) yang berisi kerangka penjenjangan 
kualifikasi kerja yang menyandingkan, menyetarakan, mengintegrasikan, sektor pendidikan dan pelatihan serta pengalaman kerja dalam rangka pemberian pengakuan kompetensi kerja sesuai dengan jabatan kerja di berbagai sektor.

Di samping itu, dalam rangka mempersiapkan generasi emas di tahun 2045 yang memiliki keterampilan masa depan yaitu 21st century skills yang (1) memiliki cara berpikir yang kreativitif dan inovatif, berpikir kritis, memecahkan masalah, membuat keputusan, dan belajar untuk belajar dan metakognisi, (2) memiliki cara bekerja yang komunikatif dan kolaboratif, (3) menggunakan alat untuk bekerja berupa literasi informasi dan literasi ICT, serta (4) hidup di dunia (1) kewarganegaraan (lokal dan global) (2) kehidupan dan karir (3) tanggung jawab personal dan sosial, kesadaran dan kompetensi kultural (Griffin, 2012 dalam Kartadinata, 2012).

Dua kekuatan tarik menarik antara tuntutan mutu dan tuntutan perluasan akses masyarakat terhadap pendidikan tinggi menjadi tantangan tersendiri terhadap Universitas Negeri Jakarta sebagai lembaga pendidikan yang mempersiapkan calon guru. Di satu sisi, UNJ harus meningkatkan kualitas mahasiswa dengan memberikan kualita pembelajaran yang baik sesuai dengan standard pendidikan, namun, tuntutan untuk memberikan akses yang luas juga memberi dampak pada beragamnya input mahasiswa. Terlebih lagi maraknya kritik terhadap rendahnya kualitas guru di Indonesia membuat tantangan tersendiri untuk mempersiapkan guru masa depan yang professional.

Dengan tingginya tuntutan tersebut, pendidikan tinggi harus dapat menyiapkan mahasiswa untuk mengembangkan keterampilan generik mahasiswa. Di sisi lain, mahasiswa dituntut secara terus menerus meningkatkan keterampilan dan pengetahuan mereka secara independen (Australian National Training Authority, 1998; Bennett, Dunne \& Carre, 1999; Candy, Crebert \& O'Leary, 1994; Dearing, 1997; Mayer, 1992 dalam McMahon \& Luca, Joe 2001).

Independensi dalam meningkatkan keterampilan dan pengetahuan dimungkinkan dengan keterampilan belajar yang baik. Kerampilan belajar merupakan kemampuan yang memberikan kesempatan bagi mahasiswa untuk lebih dapat beradaptasi dan memenuhi tuntutan akademik pendidikan tinggi yang berbeda dengan sekolah menengah di mana sistem pembelajrannya menuntut mahasiswa untuk memiliki kemandirian dalam belajar mulai dari perencanaan, proses dan evaluasi belajar. Selain perbedaan sistem belajar, mahasiswa dihadapkan pada tuntutan kualitas lulusan yang semakin meningkat sehingga standar proses pembelajaran dan kelulusan mata kuliah semakin meningkat.

Keterampilan belajar merupakan keterampilan dasar untuk sukses belajar di perguruan tinggi (Pauk dan Owens, 2011). Aspek-aspek keterampilan belajar juga merupakan variabel yang berkontribusi terhadap kinerja akademik mahasiswa, di antaranya motivasi (Barling \& Charbonneau, 1992); optimisme (Schulman, 1999); keterampilan mengelola waktu (Paden \& Stell, 1997). Hal ini menunjukkan pentingnya keterampilan belajar dalam mendukung kinerja akademik mahasiswa (Nonis \& Hudson 2010).

Namun, banyak mahasiswa yang mengalami kesulitan untuk beradaptasi dengan tuntutan pembelajaran di perguruan tinggi. Mahasiswa mengalami kesulitan di Perguruan Tinggi karena buruknya kebiasaan belajar dan persiapan untuk transisi ke Perguruan Tinggi (Lollis \& Eftink, 1990). Selain itu, banyaknya fenomena underachievement di perguruan tinggi banyak diakibatkan oleh kurangnya persiapan mahasiswa untuk mengikuti standar PT sehingga mereka tidak dapat berprestasi seperti yang diharapkan (Bailey, Hughes, \& Karp, 2003). Selanjutnya, Haycock dan Huang (2001) juga menemukan bahwa hampir 50\% mahasiswa tidak disiapkan secara akademik untuk belajar di PT (Balduf, 2009).

Berdasarkan survei yang dilakukan Wahyuni dan Nabilah pada 129 mahasiswa angkatan 2010 dan 2011 Jurusan Bimbingan dan Konseling FIP UNJ tentang keterampilan belajar, didapati bahwa sebanyak 68 mahasiswa $(52,7 \%)$ berada pada kategori rendah, sebanyak 29 orang $(21.7 \%)$ berada pada kategori sedang, dan 32 orang (24.8\%) berada pada kategori tinggi (Wahyuni \& Nabilah, 2011). Fenomena rendahnya keterampilan belajar mahasiswa sangat memprihatinkan, kritis kondisi kritis dan serius (Learning Assisstance Center University of Cincinaty). Mahasiswa yang memiliki keterampilan belajar yang rendah membutuhkan bantuan cepat untuk meningkatkan keterampilan belajar dalam menjalani perkuliahan di perguruan tinggi. Dengan kondisi ini mahasiswa sangat potensial untuk mendapatkan masalah serius dalam perkuliahan dan perlu mendapatkan bantuan segera.Rendahnya keterampilan belajar mengakibatkan usaha yang dikerahkan untuk belajar menjadi tidak efektif. Hal ini sejalan dengan pendapat John J. Hoover dan kawankawan (1992) yang menemukan bahwa waktu belajar berkorelasi negatif dengan prestasi belajar.

Selanjutnya, keterbatasan waktu mahasiswa 
dan perasaan tidak nyaman untuk melakukan pertemuan secara langsung bertatap muka dengan seseorang ahli merupakan alasan yang sering dikemukakan untuk meminta bantuan konselor. Kondisi ini dapat diatasi dengan penyediaan layanan dalam melalui internet dalam bentuk layanan e-therapy (Walter, 1996). Layanan bimbingan dan konseling juga mulai berkembang ke arah yang disebut sebagai e-therapy, terapi online, cyber counseling, e-counseling, web-counseling, konseling melalui media komputer, atau konseling jarak jauh (Martin, 2007). Sementara itu, Barak et. al (2009) menamakan hubungan teraputik berbasis internet sebagai internet supported therapeutic intervention, di mana self help web based therapeutic intervention merupakan salah satu jenis intervensi yang ada didalamnya. Penelitian ini akan menggunakan model yang dikembangkan oleh Barak et al.

Adanya layanan intervensi terapeutik berbasis internet akan memberi kesempatan bagi mereka yang secara sosial merasa malu, terisolasi, atau terhambat secara fisik sehingga kini mereka mampu berhubungan dengan individu lain atau pun mendapat dukungan (Fenichel, 2003, Kraus et.al, 2004). Sehingga bantuan bimbingan keterampilan belajar melalui internet memiliki peluang yang besar untuk membantu mahasiswa tanpa dibatasi oleh ruang dan waktu. Beberapa penelitian menunjukan bahwa intervensi terapetik berbasis internet dalam bentuk self help web based therapeutic juga terbukti efektif untuk mengatasi gejala depresi (Andersson et.al, 2005), gejala kecemasan dan stress (Straten, Cuijipers, Smith, 2008) panic disorder (Farvolden, et.al, 2005), meminimalisir pikiran untuk bunuh diri (Spijker, Straten, Kerkhof 2010). Sementara itu, pemanfaatan teknologi yang berkaitan dengan pengembangan study skills mahasiswa telah dikembangkan semenjak tahun 2003 oleh Ohio State University dengan nama ADAPT (Active discovery and Participation thrugh Technology) (Tuckman, 2003).

Tujuan penelitian ini adalah untuk melakukan assessment tentang kebutuhan web-based self-help therapeutic intervention melalui gambaran partisipasi digital mahasiswa dan gambaran keterampilan belajar mahasiswa di Universitas Negeri Jakarta. Penelitian ini diharapkan dapat memberikan basis empirik untuk mengembangkan web-based self-help therapeutic intervention untuk meningkatkan keterampilan belajar mahasiswa melalui website Tanya Binga.

\section{METODE PENELITIAN}

Metode penelitian yang digunakan adalah survei yang bertujuan untuk memperoleh gambaran tentang partisipasi digital dan keterampilan belajar mahasiswa sebagai basis empirik bagi kebutuhan terhadap web-based self-help therapeutic intervention untuk meningkatkan keterampilan belajar mahasiswa. Penelitian ini dilakukan pada bulan Mei sampai dengan November. Responden survei ini adalah mahasiswa Universitas Negeri Jakarta sebanyak 326 mahasiswa yang berasal dari tujuh fakultas, yaitu: Fakultas Ilmu Pendidikan, Fakultas Bahasa dan Seni, Fakultas Teknik, Fakultas Ekonomi, Fakultas Ilmu Sosial, Fakultas Matematika dan IPA, serta Fakultas Ilmu Keolahragaan.

Instrumen yang digunakan adalah angket partisipasi digital dan instrumen keterampilan belajar yaitu Learning and Study Strategies Inventory (LASSI) yang telah dikembangkan selama sepuluh tahun oleh Weinstein, Palmer and Schulte (1987).

\section{HASIL DAN PEMBAHASAN}

Seiring semakin berkembangnya pengguna internet juga telah membuka banyak peluang bagi profesi konselor, karena internet telah memberikan kelenturan bagi konselor dan profesi sejenis untuk memberikan pilihan layanan bagi calon konselinya, mulai dari waktu hingga cara layanan diberikan, layanan pun bisa diakses para anonimus (orang yang tidak memberikan data pribadinya). Dilihat dari sifatnya, layanan intervensi terapeutik melalui melalui internet terbagi menjadi dua jenis, jika yaitu noninteraktif dan interaktif (Marthin, 2007).

Jenis pertama, yaitu noninteraktif berupa situs yang berisi informasi dan nara sumber self help atau pertolongan mandiri yang merupakan nara sumber yang berisi informasi bagi pengayaan diri dan bersifat self help bagi pribadi yang membutuhkan (Sampson et.al: 2004). Jenis yang kedua adalah interaktif synchronous atau interaksi langsung teks memberikan kesempatan kepada individu-individu untuk saling berkomunikasi secara dinamis dalam waktu yang sama melalui internet antara konselor dengan konseli melalui chat atau instant messaging, dan video conference (Zack, 2004). Barak, Klein, Proudfoot (2009) membuat klasifikasi jenis intervensi melalui internet menjadi empat, yaitu (1) web based internet intervention, (2) online counseling, (3) internet-operated therapeutic software, dan (4) kegiatan online lainnya. Untuk melihat kebutuhan terhadap layanan self-help web-based therapeutic intervention untuk meningkatkan keterampilan belajar mahasiswa dilihat melalui survei terhadap partisipasi digital dan keterampilan belajar.

Partisipasi digital

Berdasarkan hasil survei yang dilakukan pada 326 orang mahasiswa Universitas Negeri Jakarta pada 
tujuh fakultas tentang akses internet di rumah, ditemukan bahwa hanya 35 orang (10.736\%) tidak memiliki akses internet di rumah, 147 orang (45,092\%) memiliki komputer atau alat lain dengan akses internet yang digunakan oleh semua anggota keluarga dan 155 orang $(47,546 \%)$ memiliki komputer atau alat lain dengan akses internet yang digunakan sendiri.

Bila dilihat dari perangkat yang dimiliki di rumah, sebanyak 42 orang $(25,153 \%)$ memiliki telepon selular yang digunakan oleh seluruh anggota keluarga, 243 orang (74,54\%) memiliki telepon selular yang digunakan sendiri, 38 orang (11,656\%) memiliki ponsel pintar (smartphone) yang digunakan oleh seluruh anggota keluarga, 106 orang (50,92\%) memiliki smartphone yang digunakan sendiri, 155 orang $(47,546 \%)$ memiliki komputer yang digunakan oleh seluruh anggota keluarga, 172 orang (52,761\%) memiliki komputer yang digunakan sendiri, 33 orang $(10,123 \%)$ memiliki tablet yang digunakan oleh seluruh anggota keluarga, dan 28 orang $(8,589 \%)$ memiliki tablet yang digunakan sendiri.

Secara khusus, jumlah waktu yang digunakan untuk mengakses internet setiap hari yang terbesar adalah 135 orang (41.411\%) menghabiskan 3-4 jam, dilanjutkan dengan 111 orang (34.049\%) sebanyak 1-2 jam, 44 orang (13.497\%) sebanyak 5-6 jam, 20 orang $(6.135 \%)$ sebanyak 9-10 jam, 16 orang $(4.908 \%)$ sebanyak lebih dari 11 jam dan yang terkecil adalah pada akses 7-8 jam sebanyak 14 orang (4,294\%).

Berdasarkan data di atas, dapat terlihat bahwa partisipasi mahasiswa dalam dunia digital sangat aktif. Hal ini didukung oleh fasilitas digital yang mereka miliki, yaitu sebagaian besar dari mahasiswa telah memiliki telepon seluler, smartphone dan komputer yang mereka gunakan sendiri tanpa harus berbagi dengan anggota keluarga yang lain. Hal ini membuat akses mahsiswa terhadap internet menjadi lebih terbuka. Hasil survei juga memperlihatkan bahwa hampir sebagian besar mahasiswa menghabiskan waktu di internet sebanyak 3-4 jam per hari. Dengan kondisi tersebut terlihat bahwa mahasiswa telah berpartisipasi aktif di dunia digital yang salah satunya adalah internet guna mendukung terlaksananya program selp help web based therapeutic intervention untuk study skills mahasiswa.

\section{Keterampilan belajar}

Berdasarkan hasil survei keterampilan belajar mahasiswa S1 UNJ sebagian besar berada pada kategori rendah yaitu sebanyak 168 orang (51.5\%), sebanyak 76 orang $(23.3 \%)$ dan 82 orang $(25.1 \%)$ berada pada kategori rendah. Dengan lebih dari $50 \%$ mahasiswa yang memiliki keterampilan belajar yang rendah dapat diartikan bahwa mereka membutuhkan bantuan untuk meningkatkan keterampilan belajar agar dapat mengikuti perkuliahan dengan baik.

Tabel 1. Gambaran Keterampilan Belajar Mahasiswa di Universitas Negeri Jakarta

\begin{tabular}{|c|c|c|c|c|c|c|c|c|}
\hline \multirow{3}{*}{$\begin{array}{l}\text { Jurusan } \\
\text { BK NR }\end{array}$} & \multirow{3}{*}{$\begin{array}{c}\text { Fakultas } \\
\text { FIP }\end{array}$} & \multicolumn{6}{|c|}{ Klasifikasi } & \multirow{3}{*}{$\begin{array}{r}\text { Jml } \\
25\end{array}$} \\
\hline & & \multicolumn{2}{|c|}{ Tinggi } & \multicolumn{2}{|c|}{ Sedang } & \multicolumn{2}{|c|}{ Rendah } & \\
\hline & & 4 & 16 & 9 & 36 & 12 & 48 & \\
\hline BK R & FIP & 6 & 23.1 & 8 & 30.8 & 12 & 46.2 & 26 \\
\hline $\begin{array}{l}\text { Bahasa } \\
\text { Inggris A }\end{array}$ & FBS & 9 & 39.1 & 5 & 21.7 & 9 & 39.1 & 23 \\
\hline $\begin{array}{l}\text { Bahasa } \\
\text { Inggris B }\end{array}$ & FBS & 5 & 17.9 & 11 & 39.3 & 12 & 42.9 & 28 \\
\hline $\begin{array}{l}\text { Ekonomi } \\
\text { Akuntansi }\end{array}$ & FE & 9 & 31 & 5 & 17.2 & 15 & 51.7 & 29 \\
\hline
\end{tabular}

\section{Pembahasan}

Berdasarkan kondisi di atas dapat disimpulkan bahwa mahasiswa UNJ masih membutuhkan bantuan dalam meningkatkan keterampilan belajar mereka terutama pada komponen keterampilan pada aspek menentukan ide utama. Hal ini menjadi krusial karena salah satu tuntutan sebagai seorang mahasiswa adalah membaca dan menulis ilmiah. Bila mahasiswa kesulitan dalam menentukan ide utama, tak ayal mereka akan mengalami kesulitan dalam membaca dan menulis ilmiah. Terlebih lagi dalam pembuatan skripsi yang mungkin saja dapat menghambat penyelesaian studi mereka.

Berdasarkan hasil survei tentang keterampilan belajar dan partisipasi digital mahasiswa menunjukkan bahwa mahasiswa membutuhkan layanan untuk membantu mereka meningkatkan keterampilan belajar mereka. Kondisi di mana sebagian besar mahasiswa UNJ memiliki keterampilan belajar yang rendah perlu mendapatkan perhatian serius dari berbagai pihak baik di tingkat fakultas maupun universitas. Hal ini penting untuk dilakukan didukung oleh apa yang dikemukakan oleh Lleras (2008) bahwa keterampilan belajar, kehati-hatian (conscientiousness), dan keterampilan sosial berhubungan dengan prestasi belajar (educational attainment). Sementara Robbins dan kawan-kawan (2004) mengidentifikasi beberapa hubungan antara prediktor nonkognitif dan prediktor kognitif dilaporkan bahwa keterampilan belajar memiliki hubungan yang tinggi dengan hasil GPA dan skor tes terstandar. Terutama keterampilan belajar berhubungan langsung dengan nilai mata kuliah dan hubungan langsung dengan skor tes terstandar.

Selanjutnya, Noble, Davenport, Schiel, \& Pommerich, (1999) menemukan bahwa keterampilan belajar berhubungan secara langsung dengan nilai 
GPA di mana GPA berhubungan langsung dengan skor tes yang terstandar. Noble, Davenport, Schiel, \& Pommerich, (1999) berargumen bahwa perilaku akademik berhubungan dengan kinerja pada mata kuliah yang positif yang berhubungan dengan tes prestasi. Beberapa studi seperti Kern, Fagley, \& Miller, 1998; Robbins et al., 2002; Robyak, Downey, \& Ronald, 1979) memperlihatkan hubungan yang positif antara perilaku akademik dengan nilai akhir GPA. Akhirnya, terdapat banyak penelitian seperti Elliot, McGregor, \& Gable, 1999; Robbins et al., 2002) merekomendasikan bahwa tujuan prestasi (achievement goals) dan keterampilan belajar keduanya berhubungan dengan hasil kinerja di perkuliahan (dalam Robbins dkk, 2004).

Hasil penelitian di atas menunjukkan pentingnya keterampilan belajar bagi mahasiswa untuk dapat bertahan di perkuliahan dan mencapai hasil yang baik. Sementara hasil studi pendahuluan yang menunjukkan bahwa 51.5\% mahasiswa UNJ berada pada kategori rendah dapat mengancam keberhasilan studi mereka. Balduf (2009) menemukan keterampilan belajar yang redah, manajemen waktu yang buruk dan motivasi internal dan eksternal yang rendah berkontribusi pada hasil belajar yang rendah (underachievement) pada mahasiswa S1.

Salah satu alternatif untuk membantu mahasiswa meningkatkan keterampilan belajar adalah dengan workshop keterampilan belajar. Namun, pada beberapa perguruan tinggi, banyak mahasiswa resisten mengikuti program keterampilan belajar karena beberapa mahasiswa tidak mau mengubah kebiasaan belajar mereka, tidak dapat mengubah keterampilan belajar mereka, dan mereka yakin bahwa keterampilan belajar yang baru tidak bermanfaat (Yuksel, 2006). Untuk mengatasi hal tersebut, layanan self-help web based therapeutic intervention melalui website tanyabinga dapat menjadi pilihan untuk membantu mahasiswa meningkatkan keterampilan belajar mereka.

Barak, Klein, Proudfoot (2009) membagi tiga subtipe dari web based intervention yaitu, (1) web-based education intervention, (2) self-help web based therapeutic intervention, dan (3) human-supported web-based therapeutic intervention. Barak, et.al juga membuat spesifikasi empat komponen utama dari web based intervention. Komponen-komponen tersebut adalah (a) program content, (b) multimedia use/choices, (c) provision of interactive online activities, dan $(\mathrm{d})$ provision of guidance and supportive feedback. Baik self-guided maupun humansupported web-based therapeutic interventions, secara khusus dirancang untuk mencipatakan perubahan kognisi, perilaku dan emoosi yang positif. Konten atau isi dari keduanya diformulasikan dalam sebuah sistem yang komprehensif dan diberikan dalam bentuk mudulisasi dengan format yang sangat terstruktur. Program self-guided web based intervention juga mengundang beragam format multimedia dan aktivitas interaksi online, dengan kategori sedang sampai sangat dinamis.

Sebagai tambahan, banyak self-guided therapeutic interventions dalam beberapa tingkat memberikan umpan balik otomatis, sebagian besar dalam bentuk teks grafis melalui kotak pop-up dan atau email/SMS yang dikirim secara otomatis. Kecanggihan software dan algoritma yang dikembangkan menentukan sejauh mana umpan balik dapat secara khusus disesuaikan. Penyesuaian otomatis berkisar dari tidak ada (umpan balik) sebagian (contoh: umum/pengingat sederhana, koreksi, kesesuaian atau umpan balik diagnosis), dan tinggi (contoh: pengingat, konformasi, koreksi, diagnosis, penjelasan, merekomendasikan, umpan balik elaborasi, termasuk rekomendasi yang spesifik untuk perubahan) (Flemming \& Levy,1993).

Pada saat ini, Universitas Negeri Jakarta belum memiliki program khusus yang dapat menjangkau mahasiswa secara lebih luas dalam meningkatkan keterampilan belajar dan membantu mahasiswa ketika menghadapi kesulitan dalam belajar. Potensi penggunaan internet di kalangan mahasiswa untuk kegiatan sehari-hari dan akademik serta keterbatasan waktu yang dimiliki mahasiswa di kampus merupakan indikasi bahwa mahasiswa sangat berpeluang untuk menggunakan program bimbingan yang diberikan melalui internet. Dengan demikian, salah satu alternatif untuk meningkatkan keterampilan belajar mahasiswa adalah melalui model Self help web based therapeutic intervention untuk study skills melalui website cybercounseling Tanya Binga. Model ini secara khusus didesain untuk memenuhi kebutuhan layanan bimbingan keterampilan belajar bagi mahasiswa melalui internet. Pengembangan model bimbingan keterampilan belajar perlu dikembangkan dalam rangka merespon kondisi kerampilan belajar mahasiswa yang kritis. Dengan adanya model Self help web based therapeutic intervention untuk study skills dapat memberikan jalan keluar bagi mahasiswa yang membutuhkan layanan bimbingan namun malu, takut dan tidak memiliki banyak waktu untuk berkonsultasi secara tatap muka.

Pengembangan model self help web based therapeutic intervention untuk study skills telah sejalan dengan salah satu tujuan pusat komputer UNJ, yaitu pengembangan infrastruktur jaringan komputer. Saat ini UNJ telah memiliki server dengan kapasitas sangat besar dan teknologi terkini, jaringan internet 
melalui kabel dan fasilitas Wifi yang bisa diakses oleh stakeholder UNJ di lingkungan kampus kapan saja. Penggunaan Wifi di lingkungan kampus dilakukan semenjak tahun 2000an di Amerika. Salah satu alasan utama lembaga pendidikan menggunakan fasilitas ini adalah karena lebih hemat jika dibandingkan dengan penggunaan jaringan kabel pada umumnya (Carlson, 2000; Kuo, 2005).

Dengan adanya model self help web based therapeutic intervention untuk study skills bagi mahasiswa UNJ sangat membantu dosen-dosen terutama penasehat akademik dalam rangka memfasilitasi mahasiswanya untuk mengembangkan potensi keterampilan belajarnya. Secara lebih khusus, hasil penelitian ini dapat dijadikan basis empirik untuk mengembangkan website cyber counselling Tanya Binga.

\section{PENUTUP}

Berdasarkan hasil penelitian di atas, dapat disimpulkan bahwa partisipasi mahasiswa Universitas Negeri Jakarta di dalam dunia digital cukup memadai untuk dikembangkannya model intervensi berbasis web. Selain itu, kondisi keterampilan belajar mahasiswa Universitas Negeri Jakarta cukup memprihatinkan karena lebih dari $50 \%$ memiliki ketermpilan belajar yang rendah. Dengan demikian, pengembangan model hipotetik self help web based therapeutic intervention untuk study skill melalui website Tanya Binga merupakan solusi terhadap masalah dan kondisi mahasiswa Universitas Negeri Jakarta. Di samping itu, perlu dibangun strategi kolaborasi antara pihak universitas, Kementerian Pendidikan dan pihak swasta baik di dalam maupun di luar negeri untuk menjamin keberlanjutan (sustainability) program tersebut.

\section{DAFTAR PUSTAKA}

Balduf, M. (2009). “Underachievement among college students". Journal of Advanced Academics, Vol 20. 2, Winter, pp. 274-294

Barak, A., Klein, B., \& Proudfoot, J. (2009). “Defining internet supported therapeutic intervention". Society of Behavioral Medicine. Vol. 3, pp. 4-17
Bonwell, C C., \& Eison, J.A. (2003). Active learning: creating excitement in the classroom, James Rhem \& Associates, LLC, diunduh pada 14 Maret 2010, dari http:/ / www.ntlf.com/html/lib/ bib/digests.htm"

Edward, N.S. (2003). "First impressions last : An innovative approach to induction". Active Learning in Higher Education 2003 4: 226.

Hoover, J.J. \& Jacobs, C.C. (1992). “A survey of American Indian college students: Perceptions toward their study skills/college life". Journal of American Indian Education, Volume 32 Number 1 October 1992

McMahon, M. \& Luca, J. (2001). “Assessing students' self-regulatory skills", The ASCILITE 2001 Conference Proceedings, Australia.

Office of Educational Services, Learning Assistance Center (LAC) University of Cincinnati. (2003). Helping students become more strategic learners: Learning and study strategies inventory (LASSI) user manual. USA: University of Cincinnati

Pauk, W. \& Owens, R.J.Q. (2011). How to study in college. Australia: Wadsworth

Richardson, J.S., Robnolt, V.J., \& Rhodes, J.A. (2010). "A history of study skills: Not hot, but not forgotten, reading improvement". Summer 2010; 47, 2; ProQuest Education Journals, pg. 111

Robbins, S. B., Lauver, K., Le, H, Davis, D., \& Langley, R., (2004). “Do psychosocial and study skill factors predict college outcomes? A metaanalysis". Psychological Bulletin, USA: the American Psychological Association, Vol. 130, No. 2, 261-288.

Sarath A. N. \& Gail I.H., (2010). "Performance of college students: Impact of study time and study habits". Journal of Education for Business, 85: 229-238, USA: Taylor \& Francis Group

Tuckman, B. W (2003). The strategies-for-achievement approach for teaching study skills. Applying psychological principles to teaching self-regulation and learning strategies. Toronto: American Psychological Association

Yuksel, S. (2006). “Undergraduate students' resistance to study skills course". Proquest Education Journals. Mar 2006; 40, 1. 